\title{
UTICAJ DRUŠTVENIH MEDIJA NA PROCES ODABIRA DOMAĆE DESTINACIJE KULTURNOG TURIZMA
}

\author{
Jovana Miljković', Tamara Božović
}

\section{Apstrakt}

Kulturni turizam i kulturno iskustvo predstavljaju veliki potencijal za razvoj domaćeg turizma, ali su takođe i veliki izazov. Mnogi lokaliteti kulturnog nasleđa u Srbiji još uvek nisu dovoljno poznati, a glavni razlozi su loše uređenje lokacija i nedovoljna promocija. Mnogim ljudima društvene mreže postale su osnovni izvor informacija i najbolji način za odabir njihove sledeće destinacije. U Srbiji su Facebook i Instagram najpopularnije društvene mreže. Zahvaljujući ovim društvenim mrežama, otkriva se veliki broj nepoznatih ili manje poznatih turističkih destinacija u Srbiji i stiče popularnost, stvarajući bolji imidž destinacije. U poslednjih nekoliko meseci, zbog pandemije Covid-19, deo domaćeg stanovništva je odlučilo da provede odmor u Srbiji i posete kulturne i prirodne znamenitosti koje naša država može da ponudi. Porastao je broj Facebook grupa na kojima meštani dele svoje fotografije sa putovanja, utiske, savete i preporuke. Dodavanje Instagram heštegova (hashtags) na objave, povećava se vidljivost destinacije i promocija kulturnog turizma u Srbiji. Zahvaljujući vezi između društvenih mreža i gugl mapa (Google maps), korisnici prilikom objavljivanja mogu označiti lokaciju na kojoj je fotografija nastala. Na ovaj način svi korisnici koji vide fotografiju mogu vrlo brzo saznati o kojoj destinaciji je reč. Zahvaljujući društvenim mrežama, informacije su dostupne na samo jedan klik.

Cilj ovog rada je da prikaže na koji način socijalni mediji utiču na promociju kulturnog turizma u Srbiji, dobijanjem pouzdanih informacija pregledom društvenih mreža i objava, kao i anketiranjem korisnika društvenih mreža.

Ključne reči: Kulturni turizam; Facebook; Instagram; društveni mediji, društvene mreže

1 MSc Student, Department of geography, tourism and hotel management, Faculty ofSciences, University of Novi Sad, Serbia Corresponding author, e-mail: miljkovic.jovana.95@gmail.com

2 PhD Student, Department of geography, tourism and hotel management, Faculty of Sciences, University of Novi Sad, Serbia 


\title{
THE INFLUENCE OF SOCIAL MEDIA ON THE PROCESS OF CHOOSING A DOMESTIC DESTINATION OF CULTURAL TOURISM
}

\begin{abstract}
Cultural tourism and cultural experience represent a great potential for the development of domestic tourism, but also a great challenge. Many cultural sites in Serbia are still not sufficiently known, and the main reasons are the poor arrangement of the sites and insufficient promotion. For many people, social networks have become a basic source of information and the best way to choose their next destination. In Serbia, Facebook and Instagram are the most popular social networks. Thanks to them, a large number of cultural tourism destinations in Serbia are being discovered and gaining in popularity, creating a better image. In the past few months, due to the covid-19 pandemic, some people have decided to spend their vacation in Serbia and to visit the cultural and natural sites that our country has to offer. Therefore, there has been an increase in the number of Facebook groups where locals share their travel photos, impressions, tips, and recommendations. Adding Instagram hashtags at posts is increasing the visibility of the destination and the promotion of cultural tourism in Serbia. Thanks to the connection between social networks and online maps, when posting, users can mark the location where the photo was taken. This way, all users who see the photo can find out very quickly where the destination is. Thanks to social media, information is available with just one click.

This paper aims to show in what way social media influence the promotion of cultural tourism in Serbia, by obtaining reliable information from researching social networks, posts on social media, and questioning social media users.
\end{abstract}

Key words: Cultural tourism; Facebook, Instagram, social media, social networks

\section{UVOD}

Ljudi su oduvek putovali. U davna vremena, putovanja su bila privilegija, ne samo bogatih, već i'slobodnih'. Sa druge strane, danas putovanja ne predstavljaju luksuz i dostupna su svima. Kako u digitalnom dobu internet ima veliku važnost, turističke destinacije koje žele da posete, ljudi najpre posećuju virtuelno, a to im omogućavaju objave na internetu i društvenim mrežama, poput fotografija i video zapisa na Instagramu ili postova na Facebook-u. Mogućnost tagovanja i check- 
ina (prijave lokacije) na društvenim mrežama pokrenulo je lavinu u otkrivanju mesta za izlet, odlazak na more, zanimljivih predela, ali i destinacija kulturnog turizma. Takođe, kulturna razmena između zemalja regiona treba umnogome da zahvali Facebooku i Instagramu. Prema podacima časopisa Al Jazeera, Exit Festival u Novom Sadu ima više od 78.000 tagova i check-ina i to samo na Instagramu (http://balkans.aljazeera.net/vijesti/kako-su-drustvene-mreze-donijele-revoluciju-uturizmu)

Karakter društvenih medija pruža istraživačima još uvek mnogo prostora za izučavanje. Pojedini među njima obradili su prve teorijske aspekte i proučavali trendove društvenih medija (Lee, 2013; Fotis, Buhalis, Rossides, 2012; Glozer, 2018; Guerreiro, Viegas, Guerreiro, 2019; Xiang, Gretzel, 2010; Xiang et al., 2014; Živković, Gajić, Brdar, 2014). Pored navedenih autora, ovom temom bavio se i autor Vucurović (2010) koji objašnja fenomen društvenih mreža, koje od početka 21. veka i dalje, doživljavaju ekspanziju uzrokovanu brzim razvojem tehnologije, koja je cenom i jednostavnošću upotrebe postala pristupačna prosečnim korisnicima. Razvoj društvenih mreža promenio je način na koji mladi doživljavaju internet. U početku internet je bio samo alat koji se koristio anonimno, dok se danas koristi javno, deo je svakodnevice i čak predstavlja stvar prestiža kod mladih ljudi. Isto mišljenje, kroz kasnija istraživanja, potvrđuje i autor Nakić (2017) koji navodi da je razvoj informacijsko-komunikacijske tehnologije rezultirao promenama pravila poslovanja, samim tim i pojavom novih oblika marketinga. Društvene mreže postale su učestali oblik komuniciranja, ali i ključan deo komunikacijske strategije. S obzirom da društvene mreže imaju veliki broj korisnika koji su svakodnevno aktivni, a osnova mreža je povezivanje i informisanje, veoma su privlačne za marketing. Novi talas primene interneta u svim poljima donele su društvene mreže, a turizam je delatnost kod koje društvene mreže imaju zasigurno najveći potencijal (Stojković, 2013). Društvene mreže svojom pojavom na internetu, donose promene koje značajno mogu uticati na turističku industriju (McGrath, 2008; Sigala, 2007; Stankov, 2010), dok autor Hjalager (2010) naglašava da društveni mediji dobijaju na važnosti do te mere da će u potpunosti promeniti destinacijsku marketing praksu.

Svesna činjenice da više od $80 \%$ svetskih turista svoje putovanje počinje na internetu (Stojković, 2013), Srbija je počela da koristi svoj kulturni potencijal u promociji zemlje kao destinacije izrazito bogate kulture i kulturnog nasleđa koje u pojedinim lokalitetima i mestima, ima ne samo lokalnu i regionalnu, već i svetsku turističku vrednost. Kolika je vrednost kulturnog turizma u Srbiji svedoči i podatak da su regionalni zavodi za zaštitu spomenika kulture u Srbiji registrovali oko 2800 spomenika kulture različitog značaja i vremena nastanka (Stanković, 2002). Godinama unazad, uprkos ogromnom kapacitetu koji Srbija poseduje, lokaliteti 
kulturnog turizma ne dobijaju onoliko pažnje koliko zaslužuju, prvenstveno od strane domaćih turista.

Danas, kako više nije dovoljno samo imati atraktivnu i kvalitetnu ponudu, potrebno je da ta ponuda dođe do potencijalnih gostiju. Razvojem interneta i ekspanzijom društvenih mreža, dolazi do povećane promocije kulturnog turizma u Srbiji, približavajući tako domaćim i stranim turistima mnoge lokalitete i destinacije koje su do sada bile ili nepoznate ili su bile poznate u manjoj meri.

Uticaj koji društveni mediji imaju na promociju domaćih destinacija kulturnog turizma u Srbiji nije istražen u dovoljnoj meri. Stoga, jedan od najvažnijih ciljeva ovog istraživanja jeste objasniti povezanost društvenih medija i donošenja odluke o odabiru destinacije kulturnog turizma u Srbiji, s obzirom na dostupne podatke i rezultate sprovedenog istraživanja. Takođe, ovom studijom se želi doći do saznanja koje su funkcije društvenih mreža u marketingu, promociji i informisanju turista o destinacijama kulturnog turizma. Ovaj rad ima za cilj da pokaže koliki uticaj društvene mreže imaju na promociju kulturnog turizma u Srbiji, kao i da li postoje značajne razlike u ovim uticajima u odnosu na starost korisnika društvenih mreža. Definisanje problematike i pregled stavova domaćih turista veoma su bitni za prikaz stanja i neophodan je korak za prevazilaženje eventualnih prepreka u razvoju kulturnog turizma u Srbiji. Stavovi stanovnika žitelja Srbije mogu značajno doprineti sagledavanju trenutne situacije i dati smernice za budući razvoj i napredak. Kulturni turizam predstavlja ozbiljnu razvojnu šansu za Srbiju te ova tema može biti od izuzetnog značaja za formulisanje strategije razvoja turizma u kako na nacionalnom, tako i na međunarodnom turističkom tržištu.

\section{PREGLED LITERATURE}

\section{Kulturni turizam nekada i sada}

Svedoci smo da turizam poslednjih decenija u mnogim državama postaje sve važnija privredna delatnost i jedan od najbrže rastućih privrednih sektora. Kako autor Trajković (2019) ističe, sve više ljudi putuje, povećava se kvalitet turističke ponude, a samim tim raste i prodaja turističkih usluga, te na tržištu vlada velika konkurencija, a ističe se samo najoriginalnija turistička ponuda. Iz tog razloga, neophodno je pratiti ponašanje konkurenata i na osnovu analize trenutnog stanja na tržištu predvideti budućnost, i uspešno odgovoriti na zahteve turističkih potrošača. 
Raznolikost i bogatstvo kulturnih resursa sastavni su deo turističkog proizvoda Srbije i jedna od njenih fundamentalnih konkurentskih prednosti. Na samom početku veoma je bitno definisati fenomen kulturnog turizma. Naime, kulturni turizam kao veoma široka oblast godinama unazad je istraživan među naučnicima, pa tako autor Richards (1996) objašnjava pojam kulturnog turizma kao „Kretanje osobe do kulturne atrakcije od matičnog mesta boravka, sa namerom da prikupi informacije i iskustva koja će zadovoljiti njene kulturne potrebe“ (p. 24). Kasnije, u svom radu, autor Hitchcock (2004) ističe da su turizam i kultura veoma povezani, jer se kultura zasniva na originalnosti, autentičnosti i još mnogo toga, a turiste privlače ti faktori. Takođe, kulturni turizam još uvek za neke prostore predstavlja samo veliki potencijal, dok je na razvijenijim mestima nosilac turističke ponude, ekonomskog i kulturnog razvoja, navodi autor Đukić-Dojčinović (2005).

Bitno je naglasiti, da osim turistima, kulturni turizam omogućava lokalnom stanovništvu da se upozna sa kulturnim sadržajima svog stalnog mesta boravka. U svom radu, autori Mrđić i Golubović (2013) ističu važnost edukacije prvenstveno lokalnog stanovništva, kao osnova u procesu očuvanja i interpretacije kulturnog nasleđa, kako bi se što manje dešavalo da lokalno stanovništvo uglavnom ili nema nikakvo znanje, ili ima samo osnovno znanje o vrednosti nasleđa mesta u kojem živi, što može dovesti do ugrožavanja i uništenja pojedinih lokaliteta. Iz tog razloga neophodno je osmisliti promotivnu kampanju kako bi se istakao značaj nasleđa i kako bi se obezbedilo neformalno obrazovanje lokalne zajednice o značaju i očuvanju ovih lokaliteta. Kako bi se obezbedila osnova za razvoj turizma, danas i u budućnosti, prirodno i kulturno nasleđe moraju biti zaštićeni i kako navodi autor Trajković (2019) osnovni princip kojim treba da se vodi privreda, sa ciljem razvoja održivosti turizma, jeste upravo razmatranje zaštite i razvoj turizma kao sredstva očuvanja nasleđa.

Kako se menjaju navike potrošača, menjaju se i turistička putovanja i definicije različitih oblika turizma. Tako je, na 22. sednici Svetske turističke organizacije, održane u Kini, septembra 2017. godina, Generalna skupština ponudila novu definiciju kulturnog turizma, menjajući fokus sa opipljivog na neopipljivo prirodno nasleđe: „Kulturni turizam je vrsta turističke aktivnosti u kojima je osnovni motiv posetioca da nauči, istraži, doživi i konzumira opipljive i neopipljive kulturne atrakcije i proizvode na turističkoj destinaciji (UNWTO, 2017). Na osnovu toga, autor Sančanin (2019) objašnjava da se razvoj kulturnog turizma zasniva i na opipljivom i neopipljivom kulturnom nasleđu. Osim osnovne turističke ponude, ističe se i značaj opšteg utiska koji destinacija ostavlja na posetioce, te je bitno povećati zadovoljstvo turista, što za rezultat daje lojalne potrošače i njihov povratak na destinaciju. Takođe, vremenom se sve više povećava broj turista koji pronalaze motivaciju u neopipljivom kulturnom nasleđu i naglašena je 
njihova zainteresovanost za različim kulturnim sadržajima, poput gastronomskih proizvoda, rituala, ručno pravljenih proizvoda i interpretacije kulturnog nasleđa (Filipović, 2018).

\section{Uticaj društvenih medija}

Danas, usled sve prisutnijeg razvoja savremenih tehnologija i sve veće dostupnosti podataka, dobra promocija turističke destinacije je jedan od najvažnijih delova u upravljanju turističkom destinacijom, što dokazuje činjenica da je upravljanje marketingom turističke destinacije zauzelo centralno mesto $u$ turističkim istraživanjima. S tim u vezi, autori Zlatanov i Popesku (2019) u svom radu ukazuju na to da marketinške aktivnosti, koje su sprovedene na nivou turističkih destinacija imaju za cilj da privuku potencijalne turiste da posete destinaciju i koriste sve usluge koje su dostupne u njoj. Kako savremeno turističko tržište karakteriše rast tražnje za originalnim i autentičnim proizvodima, tako se i mišljenja i želje turista menjaju, od želje za posedovanjem materijalnih dobara i usluga, ka želji da iskuse i dožive nešto novo, te se destinacijski menadžment organizacije prilagođava novim trendovima, kreiranjem novih turističkih proizvoda koji čine da iskustvo turista tokom boravka na destinaciji nezaboravnim, kako bi se ostvarilo njihovo zadovoljstvo (Zlatanov \& Popesku, 2019).

Sa druge strane, takođe veoma bitan segment u današnjem vremenu predstavljaju društvene mreže, koje su razvojem tehnologije, postale važan onlajn (online) alat koji utiče na živote ljudi, posebno na trgovce, širenjem savremenih oblika komunikacije. Iz tog razloga, razvijaju se novi oblici reklamiranja i marketinških strategija. To dovodi do toga da tradicionalna propaganda nema više isti efekat kao ranije, jer na većinu savremenih potrošača utiče sadržaj društvenih mreža, gde provode veliki deo vremena (Peković i sar., 2019). Prilikom donošenja odluke u odabiru destinacije, došlo je do dve velike promene tokom poslednjih decenija. Razvoj veb (web) stranica i platforma za informisanje potrošača, koje koriste milioni aktivnih korisnika, je jedna od promena. Druga velika promena jeste razvoj internet servisa i društvenih medija, koji postaju tehnološki alati, te se razvijaju platforme na kojima turisti mogu da dele priče o putovanjima, dopunjuju sadržaje koje su stvorili drugi korisnici, čime se vrši promocija turističke destinacije i turističkih proizvoda (Süli\&Martyin-Csamangó, 2020). Kako autori ističu, danas je korišćenje interneta svakodnevno, te predstavlja najlakši i najbrži način da se dođe do informacija. Turisti, pre nego što se odluče da otputuju na destinaciju, uglavnom provere na internetu iskustva i mišljenja ljudi koji su već posetili destinaciju, što dodatno otežava poslovanje turističkih agencija. Naime, 
kako autor Stojanović (2014) dodaje u svom radu, ukoliko potencijalni turista istraživanjem destinacije na internetu naiđe na nekoliko loših ocena određenog mesta, korisnika koji su bili na destinaciji, stvaraju negativno mišljenje o njoj, te je jako teško da radnik u turističkoj agenciji može da promeni njegovo mišljenje. Time opada interesovanje turista za određenu destinaciju, a turističke agencije moraju stalno da budu u potrazi za novom i boljom turističkom ponudom. Kako je danas potrošačima važno da mogu brzo i lako da dođu do određenih informacija, društvene mreže mogu da budu pravi način promocije turističke destinacije.

Analizom trendova novih tehnologija, potrošači su postali fleksibilniji i lakše se prilagođavaju, čime se stvara novi tip korisnika - digitalni. Autori ističu da danas postoji mnogo oblika komunikacije, gde potrošači mogu da pretražuju, dele i komuniciraju sa drugim korisnicima. Razvile su se platforme na kojima korisnici zajedno formiraju sadržaje. Među njima su Facebook, Twitter, Instagram, Snapchat, TripAdvisor, travel blogovi, kao i mnogi veb-sajtovi (web-sites) koji su direktno povezani sa turizmom. Ovde se sakupljaju i dele informacije koje mogu biti od značaja za potencijalne turiste. Danas ove platforme predstavljaju dominantne kanale komunikacije, prilikom čega se personalizuju onlajn (online) iskustva, te postoji mogućnost pronalaska svih bitnih informacija na jednom mestu (Živković i sar., 2015).

S obzirom da tema društvenih medija zauzima značajno mesto u svakodnevnom životu, ovu temu istražili su brojni autori, kao npr. Süli\&MartyinCsamangó (2020) koji su predstavili istraživanje o uticaju društvenih medija među Y i Z generacijom na odabir destinacije muzičkog festivala u Srbiji i Mađarskoj. U svom istraživanju autori su došli do podatka da ispitanici najviše koriste Fejsbuk (Facebook), ali da su jako zastupljeni i Instagram, JuTjub (YouTube) i Gugl (Google), za istraživanje destinacije, dok čak $66 \%$ ispitanika deli svoja iskustva putem Fejsbuka ili Instagrama. Slično istraživanje sproveo je autor Laskač (2019) koji je želeo da ispita navike studenata prilikom odabira turističke destinacije na društvenim mrežama, dok je glavni cilj istraživanja bio istražiti koje platforme se najviše koriste, kako utiču na odabir turističke destinacije, te koliko često ih studenti koriste prilikom donošenja odluka. Analizom rezultata, autor zaključuje da promocija putem društvenih mreža predstavlja važan strateški pristup za buđenje interesovanja kod potencijalnih turista da posete određenu destinaciju. Pored uticaja društvenih mreža, pojedini autori su istraživali i uticaj influensera na kupovne namere potrošača (Peković i sar., 2019) kako bi utvrdili u kojoj meri influenseri utiču na kupovne namere potrošača i da li poverenje potrošača ima značajan uticaj na njihovu kupovnu nameru. Kako je influenser relativno nov pojam koji nije u dovoljnoj meri istražen, nije istražen ni njihov uticaj na delatnost turizma, te to ostavlja prostora za dalja istraživanja. 


\section{METODOLOGIJA ISTRAŽIVANJA}

Istraživanje je sprovedeno sa ciljem merenja uticaja društvenih medija na lokalno stanovništvo Republike Srbije prilikom odabira destinacije kulturnog turizma u Srbiji. Uzorak se sastojao od ukupno 270 ispitanika, s tim da je jedan ispitanik rekao da ne koristi društvene mreže, te je ispitanik isključen iz uzorka. Upitnik korišćen $u$ istraživanju sastoji se od 12 pitanja, kako zatvorenih tako i otvorenih, sistematski podeljenih u tri segmenta. Podaci prikupljeni istraživanjem obrađeni su kroz program IBM SPSS23? (deskriptivna statistička analiza, t-test, ANOVA test i korelacijska analiza). Prvi segment pitanja odnosio se na sociodemografske karakteristike ispitanika koje su prikazane u tabeli 1.

Tabela 1: Socio-demografskekarakteristike ispitanika $(n=269)$

\begin{tabular}{|c|c|c|c|}
\hline Pol & Procenat (\%) & Starost & Procenat (\%) \\
\hline Muški & 14.9 & $<20$ godina & 8.9 \\
\hline Ženski & 85.1 & $21-30$ godina & 71 \\
\hline Obrazovanje & Procenat (\%) & $31-40$ godina & 6.3 \\
\hline Osnovna škola & 0 & 41-50 godina & 6.7 \\
\hline Srednja škola & 23.8 & $51-60$ godina & 6.7 \\
\hline Fakultet & 56.1 & $>61$ godina & 0.4 \\
\hline Master studije & 17.8 & & \\
\hline Doktorske studije & 2.2 & & \\
\hline Tip prebivališta & Procenat (\%) & $\begin{array}{l}\text { Koliko često koristite } \\
\text { društvene mreže? }\end{array}$ & Procenat (\%) \\
\hline Selo & 10.4 & Više puta dnevno & 94 \\
\hline $\begin{array}{l}\text { Mali grad - } \\
\text { varošica (do } 10.000 \\
\text { stanovnika) }\end{array}$ & 5.9 & Jednom dnevno & 4.5 \\
\hline $\begin{array}{l}\text { Grad srednje veličine } \\
(10.000-100.000 \\
\text { stanovnika) }\end{array}$ & 25.3 & Nekoliko puta nedeljno & 1.5 \\
\hline $\begin{array}{l}\text { Veliki grad (preko } \\
100.000 \text { stanovnika) }\end{array}$ & 58.4 & $\begin{array}{l}\text { Jednom nedeljno/ } \\
\text { ponekad }\end{array}$ & / \\
\hline
\end{tabular}

Izvor: Izrada autora 
Analizom tabele 1, vidljivo je da je veći deo ispitanika koji su učestovali u istraživanju ženskog pola (85.1\%), dok se manji broj muškaraca odazvao na učešće $u$ istraživanju (14.9\%). Pretpostavlja se da je glavni razlog nižeg procenta odgovora muškaraca slabije korišćenje društvenih mreža i manja zainteresovanost muškaraca da samostalno organizuju putovanje. Kada je u pitanju uzrast, najviše ispitanika pripada starosnoj kategoriji 21-30 godina (71\%), najmanje ispitanika je u kategoriji stariji od 61 godine $(0,4 \%)$. Jednak je procenat ispitanika u starosnim kategorijama 41-50 i 51-60 (6,7\%), dok je nešto manje u starosnoj kategoriji 3140 godina (6,3\%). Ispitanici su uglavnom visokoobrazovani ljudi, pri čemu najviše pripada kategoriji fakultet $(56,1 \%)$.

Nijedan od ispitanika nije imao osnovnu školu kao najviši stepen obrazovanja. Više od polovine ispitanika $(58,4 \%)$ živi u velikom gradu, zatim slede ispitanici iz grada srednje veličine (25,3\%). Najmanje ispitanika živi u malom gradu - varošici (5,9\%). Na pitanje koliko često ispitanici koriste društvene mreže, najveći procenat ispitanika se izjasnio da koriste više puta dnevno (94\%), a nijedan ispitanik nije izjavio da društvene mreže koristi jednom nedeljno i ponekad. Kako je najveći procenat ispitanika koji koriste društvene mreže više puta dnevno, uzorak je podoban za istraživanje ove teme.

\section{Deskriptivna statistička analiza}

Drugi segment pitanja odnosio se na navike u korišćenju društvenih mreža ispitanika. Na početku istraživanja, bitno je bilo istražiti koje društvene mreže najčešće koriste. Ispitanici su imali priliku da navedu više društvenih mreža koje svakodnevno koriste. Ne iznenađuje rezultat da je najčešće korišćena društvena mreža Facebook za koju se odlučilo $81,4 \%$ ispitanika. Zatim, $77,7 \%$ ispitanika se izjasnilo da najčešće koristi Instagram, dok njih $62 \%$ koristi YouTube. Ovi rezultati pokazuju da su ove tri društvene mreže najviše zastupljene u Srbiji. Pored navedenih, društvene mreže koje se u manjoj meri koriste su Linkedln $(8,9 \%)$, Twitter (4,8\%) i Pinterest (1,9\%). Obzirom da ispitanici najčešće koriste Facebook, Instagram i YouTube, došlo se do rezultata da se društvene mreže najčešće koriste u svrhu informisanja i istraživanja, komunikacije, zabave i razonode, dok se u manjoj meri koriste u poslovne svrhe.

Prilikom odgovora na pitanje kako traže informacije prilikom odabira destinacije, pored ponuđenih odgovora, ispitanici su imali priliku i da sami navedu na koji način se informišu. Značajnost ovog istraživanja potvrđuje podatak da se čak $69,5 \%$ ispitanika izjasnilo da informacije o turističkim destinacijama traži na društvenim mrežama, dok su internet stranice turističkih agencija na drugom 
mestu sa $61 \%$ odgovora. Značaj interneta ogleda se i u podatku da $36,1 \%$ ispitanika informacije pronalazi na forumima i portalima. Sa druge strane, da ne treba zanemariti ni značaj promocije "Od usta do usta", govori i podatak da nešto više od polovine ispitanika $(55,8 \%)$ destinaciju bira na tradicionalan način po preporuci prijatelja.

Na kraju drugog segmenta, istraženo je koliko često se ispitanici informišu putem društvenih mreža prilikom odabira turističke destinacije, pri čemu je najveći broj ispitanika $(45,4 \%)$ rekao da se društvene mreže za odabir destinacije koriste za svako putovanje, dok niko od ispitanika nije odabrao opciju da se informiše putem društvenih mreža za putovanje sa prijateljima. Sličan je broj ispitanika koji su rekli da se nikad ne informišu $(6,3 \%)$ i informišu samo za poslovna putovanja $(5,9 \%)$ putem društvenih mreža prilikom odabira destinacije. Putem društvenih mreža prilikom odabira turističke destinacije se ponekad informiše $30.1 \%$ ispitanika, dok to radi $12,3 \%$ ispitanika samo onda kada ne mogu da pronađu informacije putem drugih kanala.

Kako su kulturne destinacije iuticaj društvenih mreža na odabir ovih destinacija je osnova istraživanja za ovaj rad, bilo je značajno istražiti koje su najpopularnije destinacije kulturnog turizma koje ispitanici biraju. Najveći broj ispitanika je rekao da su to gradovi i stara gradska jezgra (70,6\%). Kako su manifestacije danas deo kulturne turističke ponude, ovaj ponuđen odgovor je izabralo 8,9\% ispitanika. Sličan broj ispitanika je odgovorio da najviše voli da posećuje muzeje i galerije $(6,3 \%)$ i religijske objekte $(6,3 \%)$. Arheološka nalazišta najviše voli da posećuje $4,1 \%$ ispitanika. $U$ otvorenom delu pitanja, osim destinacija kulturnog turizma, ispitanici su kao omiljenu destinaciju birali oblasti u prirodi (2,2\%), dok je 1,5\% rekao da posećuje kombinaciju svih navedenih destinacija.

Treći segment pitanja se odnosio na utvrđivanje u kojoj meri su ispitanici upoznati sa destinacijama kulturnog turizma, i koliko društvene mreže utiču na otkrivanje novih destinacija, te koliko pozitivni ili negativni komentari drugih korisnika društvenih mreža imaju uticaja na konačni odabir destinacije, bilo je potrebno da ispitanici ocene stepen slaganja/neslaganja sa datim tvrdnjama. Tom prilikom je korišćena petostepena Likertova skala ( 1 - u potpunosti se ne slažem, 2 - delimično se ne slažem, 3 - nisam siguran/na, 4 - delimično se slažem, 5 - u potpunosti se slažem). Rezultati istraživanja su prikazani u tabeli 2. 
Tabela 2: Rezultati deskriptivne statističke analize

\begin{tabular}{|l|c|c|}
\hline Tvrdnje & $\begin{array}{c}\text { Srednja } \\
\text { vrednost }\end{array}$ & $\begin{array}{c}\text { Standardna } \\
\text { devijacija }\end{array}$ \\
\hline $\begin{array}{l}\text { Upoznat sam sa destinacijama kulturnog turizma u } \\
\text { Srbiji }\end{array}$ & 3.49 & 1.0602 \\
\hline $\begin{array}{l}\text { Društvene mreže su mi pomogle da saznam za nove } \\
\text { destinacije kulturnog turizma u Srbiji za koju nisam } \\
\text { znao/la }\end{array}$ & 3.93 & 1.0936 \\
\hline $\begin{array}{l}\text { Zahvaljujući fotografijama na društvenim mrežama, } \\
\text { poželeo/la sam da posetim neku destinaciju }\end{array}$ & 4.24 & 1.0603 \\
\hline $\begin{array}{l}\text { Tuđi pozitivni i negativni komentari mi pomažu da } \\
\text { odlučim da posetim destinaciju }\end{array}$ & 3.92 & 1.0862 \\
\hline $\begin{array}{l}\text { Negativni komentari o destinaciji koju sam odlučio/ } \\
\text { la da posetim mogu uticati na to da odustanem od } \\
\text { posete }\end{array}$ & 3.15 & 1.1143 \\
\hline
\end{tabular}

Izvor: Izrada autora

Standardna devijacija se kreće od 1.0602 (Upoznat sam sa destinacijama kulturnog turizma u Srbiji) do 1.1143 (Negativni komentari o destinaciji koju sam odlučio/la da posetim mogu uticati na to da odustanem od posete). Uočava se da su ispitanici poprilično upoznati $(3,49)$ sa destinacijama kulturnog turizma u Srbiji, ali taj rezultat bi trebao da bude bolji, te da se radi bolja promocija kulturnog turizma usled velikog potencijala za dalji razvoj. $U$ današnje vreme, društvene mreže mogu da budu vid promocije kulturnog turizma, čemu doprinosi činjenica da su ispitanici saznali za nove destinacije kulturnog turizma putem društvenih mreža $(3,93)$ za koje ranije nisu znali. Fotografije koje korisnici postavljaju na društvene mreže mogu značajno da doprinesu motivaciji da se poseti destinacija, što je potvrđeno rezultatom da se ispitanici slažu sa tvrdnjom da su fotografije na društvenim mrežama povećale želju da posete destinaciju $(4,24)$, što može da bude dobra osnova za dalje promotivne aktivnosti. Na društvenim mrežama se postavlja veliki broj komentara o određenim destinacijama, a komentari korisnika koji su posetili destinaciju mogu da budu od velikog značaja u procesu donošenja odluke. Ispitanici se u velikoj meri slažu $(3,92)$ da tuđi pozitivni ili negativni komentari pomažu prilikom donošenja odluke o poseti neke destinacije. Ispitanici ipak nisu imali jasno definisan stav da li bi negativni komentari o destinaciji koju su odlučili da posete uticali na to da odustanu od putovanja (3.15), čime se može zaključiti da tuđi komentari nisu presudni prilikom donošenja odluke o poseti turističkoj destinaciji. 


\section{Rezultati T-Testa, ANOVA testa i Korelacione analize}

Radi utvrđivanja potencijalnih razlika između muškaraca i ženau odgovorima trećeg segmenta, sproveden je T-test i uočeno je da ne postoje statistički značajne razlike u odgovorima.

Kako bi se utvrdila potencijalna razlika između ispitanika različitih stepena obrazovanja, kao i starosti ispitanika, prema tvrdnjama navedenim u trećem segmentu, sproveden je ANOVA test $\mathrm{i}$ uočava se da ne postoje statistički značajne razlike. Obzirom da ne postoji statistički značajna razlika, sproveden je ANOVA test kojim se želelo doći do saznanja da li postoje statistički značajne razlike između navedenih tvrdnji u trećem segmentu i odgovora ispitanika na pitanje koliko često koriste društvene mreže. Rezultati pokazuju da ispitanici koji koriste društvene mreže više puta dnevno su ti koji u većoj meri smatraju da su zahvaljujući fotografijama na društvenim mrežama poželeli da posete neku destinaciju. Takođe, bilo je bitno uporediti navedenu skalu sa navikama ispitanika da se informišu na društvenim mrežama prilikom odabira turističke destinacije. Statistički značajne razlike su dokazane u čak 4 od 5 tvrdnji date skale. Ispitanici koji društvene mreže koriste kao izvor informacija prilikom odabira destinacije za svako svoje putovanje, u većoj meri smatraju, nego ispitanici koji nikada ili samo kada ne mogu da pronađu informacije putem drugih kanala, da su im društvene mreže pomogle da saznaju za nove destinacije $(F=5.705$, sig=0.00), kao i da su zahvaljujući fotografijama poželeli da upoznaju drugu destinaciju ( $F=5.333$, sig=0.00). Takođe, statistički značajna razlika postoji vezana za tvrdnje da pozitivni i negativni komentari mogu da doprinesu donošenju odluke $(F=3.386, s i g=0.01)$ da se destinacija poseti, ili da se od posete odustane ( $F=2.553$, sig=0.039). Razlika je primećena u odgovorima između ispitanika koji se nikada ne informišu o poseti destinaciji putem društvenih mreža i onih ispitanika koji se informišu za svako putovanje, ponekad ili onda kada ne mogu da pronađu informacije putem drugih kanala.

\section{ZAKLJUČAK}

Rezultati istraživanja pokazali su da su stanovnici Srbije upoznati sa destinacijama kulturnog turizma u Srbiji ali da još uvek postoji prostora da se to poboljša, te da su društvene mreže i promocija putem društvenih mreža pravi način da se dođe do većeg broja stanovnika Srbije koji imaju želju da posete kulturne destinacije prvenstveno u svojoj zemlji. Istraživanje je pokazalo da 
stanovništvo Srbije najčešće koriste Facebook, Instagram i YouTube i da zahvaljujući fotografijama na društvenim mrežama najčešće požele da posete neku destinaciju, te se u budućem razvoju promocije kulturnog turizma Srbije treba fokusirati upravo na ove mreže i njihove sadržaje u vidu fotografija i video sadržaja. Takođe, uvidelo se da su veoma bitan činilac donošenja odluke ispitanika u Srbiji tuđi pozitivni i negativni komentari, koji mogu da doprinesu odluci da se destinacija poseti ili da se od posete odustane. Do istih rezultata u ranijim istraživanjima došli su autori Stojanović (2014) i Süli \& Martyin-Csamangó (2020), koji ističu da ukoliko potencijalni turista istraživanjem destinacije na internetu naiđe na nekoliko loših ocena određenog mesta, korisnika koji su bili na destinaciji, stvaraju negativno mišljenje o njoj te to može negativno da utiče na odluku ispitanika da poseti destinaciju.

Stanovnici Srbije društvene mreže koriste više puta dnevno, prilikom odabira destinacije najčešće se informišu na njima i to rade uglavnom za svako svoje putovanje te je mišljenje autora da je ova tema od izuzetne važnosti za Srbiju, potvrđena. Uticaj koji društveni mediji imaju na promociju domaćih destinacija kulturnog turizma u Srbiji nije istražen u dovoljnoj meri, te je ovo istraživanje veoma značajno kao početak šireg istraživanja ove teme. Buduća istraživanja treba da uključe veći broj muškaraca i veći broj ispitanika generalno, kako bi se sagledala šira slika ispitanika u Srbiji. Takođe, za buduća istraživanja bitno je uključiti i veći broj ispitanika starijih od 30 godina kako bi se njihov stav ispitao detaljnije.

\section{LITERATURA}

1. Brdar, I. (2014). The Impact of Social Media on Tourism. Sinteza 2014-Impact of the Internet on Business Activities in Serbia and Worldwide, 758-761.

2. Buhalis, D., Jun, H.S., "E-Tourism, Contemporary Tourism Reviews”, Goodfellow Publishers Limited, Oxford, 2011., p.7

3. Đukić- Dojčinović, V. (2005). KULTURNI TURIZAM - menadžment i razvojne strategije. Beograd: Clio.

4. Filipović, N. (2018). Intangible cultural heritage as a motive for choosing the tourist destination Aranđelovac. Menadžment u hotelijerstvu i turizmu - Hotel and Tourism Management, 6(1), 53-62. https://doi.org/10.5937/menhottur1801053F

5. Fotis, J. N., Buhalis, D., \&Rossides, N. (2012). Social media use and impact during the holiday travel planning process (pp. 13-24). Springer-Verlag. 
6. Glózer, R. (2018). „Jönnekaz'Instagram-inasok'? Az Instagram szerepeéslehetőségei a turizmusmarketingben". Csapó J. (In Hungarian)

7. Hitchcock, M. (2004). Margaret Mead and tourism: Anthropological heritage in the aftermath of the Bali bombings. Anthropology Today, 20(3), 9-14.

8. Hjalager, A. (2010). A Review of Innovation Research in Tourism. Tourism Management 31 (1), pp. 1-12.

9. Laskač, L. (2019). DRUŠTVENE MREŽE KAO OBLIK PROMOCIJE TURISTIČKIH DESTINACIJA KOD MLADIH: Završni rad (Doctoral dissertation, University of Split. Faculty of economics Split.).

10. Lee, E. (2013). Impacts of social media on consumer behavior: decision making process.

11. http://www.theseus.fi/bitstream/handle/10024/62367/Lee_Ethel. pdf? sequence $=1$ \&isAllowed $=y$

12. Mrđić, N., Golubović, S. (2013). Danube limes as UNESCO world heritage Site. Archaeology and Science, Vol 9, 101-118.

13. McGrath, M. (2008). Employing „Social Network Analysis" to Influence.

14. Nakić, A. (2017). Ulogadruštvenihmreža u obavljanjumarketinškihaktivnosti (Doctoral dissertation, University of Pula. Faculty of economics and tourism" Dr. Mijo Mirković".).

15. Peković, J., Zdravković, S., \& Pavlović, G. (2019). Influenseri sa društvenih mreža kao prediktor namera potrošača. Marketing, 50(3), 207-216.

16. Richards, G. (1996). Cultural Tourism in Europe. Wallingford: CAB International.

17. Sančanin, B. (2019). Historical Heritage in The Function of Developing Cultural Tourism. The Journal of Middle East and North Africa Sciences, 5(5), 6-12.

18. Sigala, M. (2007). Web 2.0 in the Tourism Industry: a new Tourism Generation and New e-Business Models.

19. Stanković, S. (2002). Turizam u Srbiji. Srpsko geografsko društvo. Beograd.

20. Stankov, U., Lazić, L., Dragićević, V. (2010). The extend of use of basic Facebook usergenerated content by the national tourism organizations in Europe. European Journal of Tourism. Volume 3, Issue 2, pp. 105-112.

21. Stojanović, J. (2014). Savremene tendencije u turizmu. In Uticaj interneta na poslovanje u Srbiji i svetu [Elektronski izvor]/Međunarodna naučna konferencija Univerziteta Singidunum Sinteza 2014, 25.-26.04. 2014.= Impact of Internet on Business Activities in Serbia and Worldwide/Singidunum University International Scientific Conference Sinteza 2014 (pp. 738-742). Beograd: Univerzitet Singidunum. 
22. Stojković, M. (2013). Primena društvenih mreža u turizmu i ugostiteljstvu. Priručnik za osnovnu primenu društvenih mreža u promociji i plasmanu turističko-ugostiteljske ponude. Specijalizovanaagencija TMC - Tourism Management and Consulting

23. Süli, D., \& Martyin-Csamangó, Z. (2020). The impact of social media in travel decisionmaking process among the $Y$ and $Z$ generations of music festivals in Serbia and Hungary. Turizam, 24(2), 79-90.

24. Trajković, N. [2019]. Prirodni i kulturni resursi kao faktori konkurentnosti i jačanja performansi sektora turizma. Turističko poslovanje, (23), 5-15.

25. Viegas, C., Guerreiro, A., \& Veia, L. (2019). Estratégias matemáticas dos alunos em problemas de valor omisso. Revista Educação Matemática em Foco, 8(1), 28-54.

26. Vucurovic, M. (2010) Uticaj društvenih mreža Interneta na društvo, master rad, str.3, preuzetosa: https://www.researchgate.net/publication/271270026_Uticaj_drusvenih mreza_Interneta_na_drustvo

27. Vujović, S. (2016). Kako očuvati i koristiti kulturno nasleđe: doprinos vekova Bača (How to Preserve and Use Cultural Heritage: The Contribution of the Centuries of Bac). Petrovaradin: Pokrajinski zavod za zaštitu spomenika kulture.

28. World Travel Organization (WTO). (2019). UNWTO Tourism Definitions. Retrieved August 13, 2019 from https://publications.unwto.org/publication/UNWTO-Tourismdefinitions.Xiang, Z., \&Gretzel, U. (2010). Role of social media in online travel information search. Tourism management, 31(2), 179-188.

29. Xiang, Z., Wang, D., O'Leary, J. T., \&Fesenmaier, D. R. (2015). Adapting to the internet: trends in travelers' use of the web for trip planning. Journal of travel research, 54(4), 511-527.

30. Zlatanov, S., \& Popesku, J. (2019). Korišćenje društvenih mreža u aktivnostima destinacijskih marketing organizacija. Marketing, 50(3), 195-206.

31. Živković, R., Gajić, J., \& Brdar, I. (2014). The impact of social media on tourism. Singidunum Journal of Applied Sciences, 758-761.

32. http://balkans.aljazeera.net/vijesti/kako-su-drustvene-mreze-donijele-revoluciju-u-turizmu

Рад је примљен: 27. август 2020. Прихваћен за објављивање: 31. август 2020.

Received: August 27, 2020.

Accepted: August 31, 2020. 